\title{
IMPACT OF GOVERNMENT AND INTERNATIONAL ORGANIZATIONS ON FOOD SECURITY POLICY IN POLAND
}

\author{
Tomasz Słapczyński \\ Uniwersytet Marii Curie-Skłodowskiej w Lublinie \\ Wydział Politologii i Dziennikarstwa \\ ORCID ID: https://orcid.org/ 0000-0002-9636-1673 \\ e-mail: tslapczynski@gmail.com
}

\begin{abstract}
The article tries to research on how international organizations and its policy released in Poland affect the decision making process on Polish food security policy and whether the it is a stimulus for the decisions taken, or whether they are complementary to the government's already existing food security policy. The main research questions concern whether the national food security policy is at a satisfactory level or whether it is necessary to supplement it with the interference of international organizations. The article is divided on few paragraphs:, Polish national food strategy, The European Union influence on Poland's food security and organizations activities on food security in Poland, applied research methods of food security policy in Poland, analysis of the agricultural sector in Poland and general food security policy analysis in Poland. It will define basic concepts related to politics, public policy and food security. This section will also describe the role of various organizations in developing food security. Individual activities created by the organization and the government to increase food security will be also described.
\end{abstract}

Keywords: EBRD, EU, food security, economic strategy, agriculture in Poland.

\section{INTRODUCTION}

The policy concerns on power of society or in specific public policy decisions. It has several different but complementary meanings. It is used for processes in which public policies are formulated and adopted and for the role played by elected officials, organized interest groups, public opinion and political parties. In this meaning it is policy making. Politics can be understood as conflicts in society, such as attitudes towards environmental protection. It is related to social interests or values. The policy in this case refers to problem positions that various groups of people take actions to promote their values. These collections of people with 
similar interests often become active in policy making. Politics concerns power and influence in society, as well as in policy making processes in government. This applies to who participates and who influences the decisions made by governments, who gains and who loses (Kraft M. E., Furlong S. R. 2017: 42-43). Food security is one of the most important policy for citizen safety, connected strictly with public health and eradicating poverty

\section{POLISH NATIONAL FOOD STRATEGY}

Poland, in terms of the agricultural population, is on second place in the European Union in number of farms, first place belongs to Romania. But what is characteristic farms in those states are similarly small. Polish agriculture is characterized by high fragmentation, average utilized area agricultural (UAA) per 1 farm increases gradually and in 2015 (latest accurate data) amounted to 10.3 ha of arable land (in 2011 - $9.1 \mathrm{ha}$, and in 2002 -5.8 ha). Despite some acceleration of concentration, just over half of farms in Poland (51.9\%) uses no more than 5 ha. Almost 3/4 households (74.9\%) use less than 10 ha, and their total share in agricultural land is $28.3 \%$. These farms usually conduct production using traditional methods, with low mineral fertilization and chemical consumption of plant protection products as well as industrial feed, especially cattle. The next $31 \%$ of arable land is on 10-30 hectares. Over 74 thousand farms, i.e. $6 \%$ of the total population, manages almost $40.7 \%$ of arable land. In 2015 (last complex research was conducted on this data), farms in Poland has a production in global value (in current prices) that places Polish agriculture on the 7th place in the European Union after France, Germany and Italy, Spain, Great Britain and the Netherlands. In 2015 , the largest commodity structure of agricultural production was: cow's milk $(16.3 \%)$, poultry livestock $(14.7 \%)$, pigs livestock $(13.7 \%)$, cereals $(11.4 \%)$, vegetables (10.6\%), livestock and veal (7.3\%), fruit (6.3\%) and chicken eggs (5.5\%). Poland was the EU leader in the production of triticale (41.5\%), apples $(25 \%)$, cabbage $(24.3 \%)$, poultry meat $(16.1 \%)$, oats $(16.1 \%)$, carrots $(13.4 \%)$, blackcurrants (almost 75\%), and the second - producer of rye, strawberries, cucumber, and the third - producer of cereals, sugar beet, rapeseed, leek, onions. Poland also occupies a significant place in the production of potatoes, milk, cheese, butter, tobacco, tomatoes. Mineral fertilizers are important cost component in farms, which limits their level of consumption. The consumption of mineral fertilizers in the 2014/2015 season amounted to nearly 1.8 million tones per pure ingredient and was $7.4 \%$ smaller, compared to the previous season. As a consequence, the ratio was still far from the recommended one, by UE administration. The high share of nitrogen fertilizers increases, can adversely affect production processes and increase risk. In Western European states, large-scale, modern farms using genetic progress, allowing to better use environmental factors, while optimizing mineral fertilization. They also monitoring soil condition. They applying variable 
doses of fertilizers within the field. In Midwestern European states there is many programs promoting healthy food, so more important is to use organic farming and integrated production farming methods. In addition, due to degradation of agricultural habitats and environmental pollution, because of persistent mineral fertilization, some farmers try to reduce consumption of chemicals. Plant protection products schedule is included for market in Poland by European Commission. The distribution network of plant protection products in Poland is well developed and ensures availability of purchase plant protection products throughout the country. Most wholesalers is located in Mazowieckie voivodship (51), the least in the Warmian-Masurian voivodship (5). It shows that richer voivodships are more developed in this area. (Instytutu Ekonomiki Rolnictwa i Gospodarki Żywnościowej (Official Website of Polish Goverment, 2018, Rolnictwo i gospodarka żywnościowa w Polsce: 26-29 [online] Available at: https://www.gov.pl/ documents/912055/913531/Rolnictwo_PL_2014.pdf/58616346-761b-f3a2-d4831a1756d6d4ef, accessed: 20.04.2021).

The main goal of the 2030 Polish strategy for sustainable development of agriculture and fisheries is to increase the income of countryside residents with a simultaneous increase in social, economic, environmental aspects. Achieving the assumed goal will be possible thanks to the implementation of activities designed in the system of three specific objectives:

I. Increasing the profitability of agricultural and fishery production

II. Improving the quality of life, infrastructure and environment condition

III. Development of entrepreneurship, non-agricultural jobs and activate society.

Three areas influencing the implementation of the strategy's by: (1) efficient development management, (2) stable financing of development, (3) increase sustainable ability to create and learn. At the end of April 2017 Polish Minister of Agriculture and Rural Development invited for cooperation Voivodes and voivodship Agricultural Advisory Centers, entrusting them with the task of creating a team in each voivodship that will analyze the opportunities and threats facing the food policy. Also to describe rural areas in the voivodship and determine potential directions of rural development. While designing the goals and activities of the strategy, the principles are focused at (concentration, searching for niches, sectors). Integrated and territorially diverse approach (management organized around strategic goals, coordination of sectors and institutions operating at various levels of management). Cooperation, partnership and joint responsibility of public entities, business and citizens in the implementation of public policies. Mobilization of domestic capital, demographic processes as a reference point for planning and implementing development activities. It was created a term OSI - Area of Strategic State Intervention. The document emphasized that the Area of Strategic State Intervention (OSI) where are all rural areas are strongly diversified economically, socially and territorially (mainly due to differences in sources of financing for development, territorial accessibility, pace and directions of demographic and 
social changes). Government's Rural program SZRWRiR 2030's response to mega trends (such as globalization, demographic changes, digitization, climate change and greater concern for the environment). Reflect the new country development model (implementation of the responsible development model in place of the polarization and diffusion model) as a part of the Village Plan (based on three pillars: protection, support and development). The strategy introduces changes in the management system by establishing a broader agricultural dialogue, implementing a new management model, describing institutional changes and assuming greater use of a design approach in managing. Strategic choices in SZRWRiR 2030 are also a response to EU funds, which are used for 2021-2027 (mainly the Common Agricultural Policy, Cohesion Policy and the Common Fisheries Policy) for rural development, agriculture and fisheries. (Official Website of Polish Goverment, 2018, strategia zrównoważonego rozwoju 2030: 26-29 [online] Available at: https://www.gov.pl/web/rolnictwo/strategia-zrownowazonego-rozwoju-2030, accessed: 20.04.2021].

\section{THE EUROPEAN UNION AND POLAND'S FOOD SECURITY}

Another important issue from the point of view of the Polish food security policy is the European Union (hereinafter the EU) food security policy. It aims to protect consumers while guaranteeing the smooth functioning of the single market. Starting from 2003, the policy focuses on the concept of traceability of both inputs (eg. animal feed) and output products (eg. basic production, processing, storage, transport and retail sales). The EU has agreed standards to ensure food hygiene, animal health and welfare, plant health and control of pollution from external substances such as pesticides. Rigorous controls are carried out at every stage, and imports (eg. Meat) from outside the EU must meet the same standards and pass the same checks as foods produced in the EU (European Commission Official Website, 2018, Food safety: overview [online] Available at: https://ec.europa.eu/food/overview_en, accessed: 20.04.2021).

The European Commission (hereinafter the EC) also aims to ensure a high level of food safety and animal and plant health in the EU. Through consistent measures implemented in production entities and appropriate monitoring of activities while maintaining an effective and competitive internal market. The implementation of this integrated food safety policy in the EU covers various activities. Ensuring effective control systems and assessment of compliance with EU standards in the areas of food safety and quality, animal health, animal welfare, animal nutrition and plant health sectors in the EU and third states regarding their export to the EU. Manage relations with the European Food Safety Authority (EFSA) and provide scientific risk management. In addition, the food safety system includes food control. Every European citizen has the right to know how the food he eats is produced, processed, packaged, labeled and sold. The main 
objective of the European Commission's food safety policy is to ensure a high level of human health protection in relation to the food industry - the largest European production and employment sector. The main principles of the EC on food safety are defined in the so-called White Book. This is the application of an integrated farm approach, covering all sectors of the food chain. Another element of the integrated food security policy is to ensure the quality of livestock. The general objective of animal welfare policy is to ensure that animals should not suffer and oblige the owner of animals to comply with the minimum animal welfare requirements. Union zootechnical legislation aims to promote free trade in breeding animals and their genetic material, taking into account the durability of breeding programs and the preservation of genetic resources. In matters of plant care, the European Commission is actively involved in the establishment of international phytosanitary and quality standards for plants and plant products. Over the years, EU legislation has harmonized protection of the so-called "Green resources". Issues such as pesticides, plant variety rights or breeding of genetically modified organisms are some of the issues addressed by the European Commission (European Commission Official Website, 2018, Food safety: overview [online] Available at: https://ec.europa.eu/food/overview_en, accessed 20.04.2019).

The European Commission is also involved in the promotion of healthy food and food security through its policy. One of such activities is the project "Better Training for Safer Food" (hereinafter referred to as BTSF), which consists of many elements. The program has an impact on a better food quality policy, through the implementation of many activities. This includes, among other things, training of competent authorities staff to better implement EU animal health and welfare, plant health and feed and food regulations. This is particularly important in the case of a crisis, such as epidemics, which have been observed, for example, in connection with African swine fever. BTSF has around 17 million euros of budget per year and mainly deals with training. So far, it has trained over 68,000 participants on the subject of broadly understood EU food security. (European Commission Official Website, 2018, Better Training for Safer Food [online] Available at: http:// ec.europa.eu/chafea/food/index_en.htm, accessed: 20.04.2021).

\section{ORGANIZATIONS ACTIVITIES ON FOOD SECURITY IN POLAND}

Poland was one of the 44 FAO founding members participating in the "Hot Spring" conference in 1943 at the FAO founding conference in Quebec City. On October 16, 1945. FAO shared the history of cooperation with the Polish government focused on projects that improve security and efficiency of the Polish food system. In recent years, Poland has moved from the role of the recipient to the role of a food donor. The FAO recently finances research on best practices for emergency preparedness. Food security in Poland according to FAO data develops at a satisfactory pace. In recent decades, much has changed for the better as in 
developed states. In recent decades, the migration routes of fish in Polish rivers have been reopened. A few years ago, many Polish rivers were inhabited by four major migratory fish species - sturgeon, salmon, sea trout and carp. The general deterioration of the state of the environment caused a decline in the migratory fish population. However, the biggest single influence on fish was provoked by the damming of the central Vistula in Włocławek (Decyzja Prezydenta Miasta Włocławek, sygn. OS.7642-17-60/10).

Another important project coordinated by the FAO was the implementation of greenhouse technology management, increasing food efficiency. The implementation of technology lasted for many years. In particular, it was a production and protection technology (IPPT) aimed at growing tomatoes. However, this method was not effective in small family greenhouse enterprises, mainly due to limited financial resources, lower investment, poor information and limited access. The FAO has carried out a number of technical support missions, including two missions of the international expert panel with groups of agricultural producers. The Research Institute of Vegetable Plants (RIVC) in Skierniewice also participated in the project. The project was implemented in about 200 private greenhouses in farms producing tomatoes with a total area of almost 150 ha and in 75 ha of plastic tunnels. According to FAO data, the project has been successfully implemented: enabling consumers to purchase high quality, visually attractive products and nutritional value without excess external chemicals. As the General Director of FAO, José Graziano da Silva, said: "We can not improve food quality without taking care of safety, and it is impossible to achieve food security without a better systemic food policy". Additive project was supported by FAO is the sustainable development of Sudety region in the south-western part of Poland, along the border with the Czech Republic. This depopulated mountain areas face many challenges. As a result, the region underwent significant social changes in international conflicts and large population changes. In the 1990s, market reforms led to increased poverty and economic hardship for large community groups, as jobs were lost when old state-owned enterprises and farms were privatized and restructured. The situation was difficult due to the lack of organization among local farmers and producer groups, as well as the lack of real local markets for their products. Therefore, the Ministry of Agriculture and Rural Development of Poland and local governments have asked the FAO for help in implementing the program for the sustainable development of mountain areas, which consists of many systems: environmental, economic, social and cultural (FAO Official Website, 2015, Poland and FAO Partnering to achieve sustainable food systems [online] Available at: http://www. fao.org/3/az522e/AZ522E.pdf, accessed 20.04.2021). 


\section{APPLIED RESEARCH METHODS OF FOOD SECURITY POLICY IN POLAND}

The most frequently used methods of policy analysis are useful also for food security policy. The leading methods of policy analysis are connected heavily with economics and focus on the evaluative criterion of efficiency, particularly for cost-benefit and cost-effectiveness analyses (Dunn 2016:5). These methods are also useful for nontechnical analysis. Those methods are tools for critical thinking about public policy. Public policy evaluation is more than economics. It is about effectiveness, equity and politics. Analytic methods can be used to clarify problems and policy choices. The analytic methods are grouped into four categories:

1. Economic approaches that include cost-benefit analysis, cost-effectiveness analysis, and risk assessment methods.

2. Decision making and impacts, which includes forecasting and impact assessment.

3. Political and institutional analysis, which includes assessment of political feasibility as well as policy implementation and program evaluation.

4. Ethical analysis, where the concern is consideration of the ethics of policy action (Kraft M. E., Furlong S. R. 2017: 296-297).

According to (Kraft M. E., Furlong S. R. 2017: 297), in order to effectively evaluate public policy, appropriate evaluation criteria should be distinguished for the evaluation of policy proposals. The most important of them are certainly effectiveness, efficiency, justice, ethics and political values. Some methods are distinguished in the analysis of public policy. Methods of policy analysis connected with economic approach are most appropriate. In addition, cost-effectiveness, decision-making and impacts on further development of food policy in Poland makes the effect of food policy. The question of the effectiveness of investment implementation is most important. Ethical analysis in this case is not so important, because it is sometimes in opposite to economic approach (Kraft M. E., Furlong S. R. 2017: 298).

Cost-benefit analysis is one of the simplest methods and involves choosing the best option possible. Such that the benefit-cost ratio is as large as possible. This method can be considered at the level of individual business entities that want to be credited on the most favorable conditions for themselves and as was presented above.

The cost-effectiveness analysis can be referred to the overall efficiency of the entities implementing the processes. Many entities have mathematical methods to estimate the value of e.g. life (insurance companies), although many critics object to the principle of making such calculations. The analysis consists in the fact that it does not require measurements of intangible benefits, such as the impact on the environment or distortion of competitiveness, which are also important (Kraft M. E., Furlong S. R. 2017:305). 


\section{ANALYSIS OF THE AGRICULTURAL SECTOR IN POLAND}

Agriculture in Poland epitomizes the costs of delayed structural reforms. With $11.5 \%$ of the workforce employed in agriculture, the Polish countryside remains the mainstay of the economy. For this reason, long delays in reforms are worrying other sectors and the labor market in general. Agricultural productivity is low, even according to the standards of other new EU Member States in the region. The sector has benefited from a significant inflow of EU funds under the Common Agricultural Policy and from the EU Structural and Investment Funds, estimated at around EUR 34 billion over ten years until 2014. During this period, agricultural income has tripled. Modernization of equipment and processing industry caused almost four times increase in agricultural production in this period. The main obstacles to low productivity are especially the lack of consolidation. The average farm size is one of the smallest in Europe. At the beginning, polish government adopted a law that suspends land sale by a state agency and restricts the sale of land between private entities, completely prohibiting further acquisitions of entities that already own holdings of a certain size and further limit consolidation. The most persistent and costly obstacle for agricultural workers leaving the rural economy is a preferential tax system, which is largely based on the size of agricultural plots. As a result, more than 40 percent of employees in rural areas declare themselves as self-employed. This contributes to the exceptionally high share of contracts about precarious employment in Poland. In addition, the conditions offered by the Agricultural Social Insurance Fund (KRUS) are also better than insurance in the Social Insurance Institution (ZUS) servicing other sectors. State subsidies to the Agricultural Social Insurance Fund amount to almost 1\% of GDP, and only one tenth of the costs are covered by actual contributions. There is no system for assessing and registering farmers' incomes, which could be the basis for taxation of natural persons and social security contributions. As in the mining sector, special privileges constitute a factor discouraging a significant part of the workforce from moving away from the unproductive sector, despite the fact that agricultural workers are statistically relatively young and educated. (EBRD Official Website, 2018, Poland overview [online] Available at: https://www.ebrd. com/where-we-are/poland/overview.html, accessed 20.04.2019).

\section{GENERAL FOOD SECURITY POLICY ANALYSIS IN POLAND}

Poland have a good place in the European ranking in terms of food quality and production efficiency. Although it is not in the forefront, however, as a post-communist state, production in its area is satisfactory. It should be noted that agriculture in developed Western states has reached the current level on market conditions for many decades. Poland it switched to free market economy in 1990. It should be emphasized that food policy in Poland stands at a good 
level not only thanks to the efforts of the Polish government but also thanks to the institutions of the European Union, which financially supports Polish agriculture. The European Union also provides organizational foundations through directives. It is very important and significant for the European Union, because they are well-thought-out and well-developed strategies that have been worked on for many years, a professional way, a policy has been developed to be effective. I think it is good for food policy both in the whole European Union and in Poland. It should be noted that Polish agriculture is constantly developing and adapting to modern trends, Polish agriculture puts great emphasis on organic production, which seems to be its biggest advantage. Summarizing the state of Polish food seems to be at a satisfactory level, of course, it can be mentioned that Polish food is not controlled in a good level, it can be seen on the example of scandals disclosed. However, in general, it is not possible to generalize these cases, it is known that organic food is better quality but is more expensive. The choice of purchased products in this case depends on the consumer. Although the poorer society buys fewer organic products, because it is more expensive (sometimes poor produces organic food for themselves, but in small amount, because it is not so effective economically). However, this is an economic principle that cannot be undermined. Food producers must earn on sales, if production is expensive and the product must have a higher price.

Another issue is food security in terms of access to food for society. It seems that Poland as a state with developed agriculture should not have problems with providing access to food for its citizens. In this aspect Poland is self-sufficient and it can be assessed very well.

Tytul: Wpływ rządu i organizacji międzynarodowych na politykę bezpieczeństwa żywnościowego w Polsce

Streszczenie W artykule podjęto próbę zbadania, w jaki sposób organizacje międzynarodowe i ich polityka wpływają na proces podejmowania decyzji dotyczących polskiej polityki bezpieczeństwa żywnościowego. Czy stanowią one bodziec dla podejmowanych decyzji, czy są one uzupełnieniem już istniejącej polityki rządu dotyczącej food security. Główne pytana badawcze dotyczy tego czy narodowa polityka food security jest na zadowalającym poziomie czy niezbędne jest jednak uzupełnienie jej poprzez ingerencję organizacji międzynarodowych. Artykuł podzielony jest na kilka akapitów: polska narodowa strategia żywnościowa, wpływ Unii Europejskiej na bezpieczeństwo żywnościowe Polski i działania organizacji na bezpieczeństwo żywnościowe w Polsce, stosowane metody badań polityki bezpieczeństwa żywnościowego w Polsce, analiza sektora rolnego w Polsce oraz ogólne analiza polityki bezpieczeństwa żywnościowego w Polsce. Zdefiniowano podstawowe pojęcia związane z polityką, porządkiem publicznym i bezpieczeństwem żywnościowym. Opisano również rolę różnych organizacji w rozwoju bezpieczeństwa żywnościowego. Scharakteryzowane zostaną także indywidualne działania podejmowane przez organizacje międzynarodowe i rząd w celu zwiększenia bezpieczeństwa żywnościowego.

Słowa kluczowe: EBOR, UE, bezpieczeństwo żywnościowe, strategia gospodarcza, rolnictwo w Polsce. 


\section{REFERENCES}

1. FAO (1996), Declaration on world food security. World Food Summit, FAO, Rome.

2. Kraft M. E., Furlong S. R. 2017. Public Policy: Politics, Analysis, and Alternatives.

3. Morrison, J.A. \& Pearce, R. 2000. The Impact of Further Trade Liberalisation on the Food Security Situation in Developing States. OECD Paris.

4. OECD (2002). The medium term impacts of trade liberalisation in OECD states on the food security of non-member states. Paris: OECD.

5. OSCE/ODIHR: Republic of Poland, Parliamentary Elections, 25 October 2015, Election Assessment Mission Report, Warsaw, 26 January 2016,

6. Pinstrup-Andersen P., 2009. Food security: definition and measurement. Springer Science + Business Media B.V. \& International Society for Plant Pathology.

7. Poland and FAO Partnering to achieve sustainable food systems, http://www.fao.org/3/az522e/ AZ522E.pdf,

8. Poland Country Strategy 2018-2023 as approved by the Board of Directors on 11 April 2018 document, https://www.ebrd.com/where-we-are/poland/overview.html,

9. Poland diagnostic paper: Assessing progress and challenges in developing a sustainable market economy (2018), London, s. 8. https://www.ebrd.com/where-we-are/poland/overview.html,

10. Timmer P.. Walter C., Falcon P., Pearson S. R., (1983) Food Policy Analysis, Baltimore and London.

11. Timmer, C. P., 2015. Food Security and Scarcity (Why Ending Hunger Is So Hard) The Political Economy Of Food Security: Food Price Volatility And Policy Responses. Philadelphia,

12. USDA (1999). Food Security Assessment. USDA Economic Research Service. Situation and Outlook series GFA-11 Washington DC.

13. FAO (1999). Agricultural Trade and Food Security. Agricultural Trade Factsheet - Third Ministerial Conference. Rome, FAO,

14. http://ec.europa.eu/chafea/food/index_en.htm, (accessed 26.06.2021).

15. http://www.fao.org/countryprofiles/index/en/?iso3=POL, (accessed 26.06.2021).

16. http://www.ippt.pan.pl/Repository/o2093.pdf, (accessed 26.06.2021).

17. http://www.polreff.org/o-programie.html, (accessed 26.06.2021).

18. http://www.polseff.org/, (accessed 26.06.2021).

19. https://ec.europa.eu/food/overview_en, (accessed 26.06.2021).

20. https://ec.europa.eu/food/plant/plant_health_biosecurity/europhyt/network_en, (accessed 26.06.2021).

21. https://ec.europa.eu/food/safety/rasff_en, (accessed 26.06.2021).

22. https://eur-lex.europa.eu/summary/chapter/food_safety.html?root_default=SUM_1_ CODED\%3D30\&locale $=$ en, (accessed 26.06.2021).

23. https://eur-lex.europa.eu/summary/chapter/food_safety/3010.html?root=3010, (accessed 26.06.2021).

24. The Food and Agriculture Organization, http://www.fao.org/3/y4671e/y4671e05.htm\#TopOfPage, (accessed 26.06.2021).

25. http://documents.worldbank.org/curated/en/308741468762347702/Food-policy-analysis, (accessed 26.06.2021).

26. Decyzja Prezydenta Miasta Włocławek z dnia 6 kwietnia 2011 roku o środowiskowych uwarunkowaniach dla przedsięwzięcia polegającego na przebudowie i remoncie obiektów Stopnia Wodnego we Włocławku (sygn. OS.7642-17-60/10). 